\title{
EVALUATION OF ANALGESIC AND ANTI-INFLAMMATORY EFFECTS OF ETHANOL EXTRACT OF FICUS ITEOPHYLLA LEAVES IN RODENTS
}

\author{
Abdulmalik I.A ${ }^{* 1,2}$, Sule M.I ${ }^{2}$, Musa A. $\mathbf{M}^{2}$, Yaro. A. $\mathbf{H}^{3}$, Abdullahi M.I ${ }^{2}$, Abdulkadir M.F ${ }^{1}$ and \\ Yusuf $\mathbf{H}^{1}$
}

\author{
${ }^{1}$ Department of Applied Science, C.S.T. Kaduna Polytechnic-Nigeria, ${ }^{2}$ Department of Pharmaceutical \\ and Medicinal Chemistry, Ahmadu Bello University, Zaria -Nigeria. \\ ${ }^{3}$ Department of Pharmacology, Faculty of Medicine, Bayero University Kano-Nigeria \\ *E-mail: ismailabdulmalik@yahoo.co.uk
}

\begin{abstract}
This study was undertaken to investigate the leaf part of the plant for analgesic and anti-inflammatory. The ethanol extract of Ficus iteophylla leaves (100, 200, and 400 $\mathrm{mgg}^{-1}$, i.p) was evaluated for analgesic and anti-inflammatory activities. The analgesic effect was studied using acetic acid-induced abdominal constriction and hot plate test in mice, while the antiinflammatory effect was investigated using carrageenan induced paw oedema in rats. The ethanol extract at $100 \mathrm{mgkg}^{-1}$, $200 \mathrm{mgkg}^{-1}$, and $400 \mathrm{mgkg}^{-1}$ significantly $(\mathrm{P}<0.05)$ inhibited acetic acid induced writhes by $1.50 \pm 0.43,3.0 \pm 0.82$ and $1.0 \pm$ 0.82 respectively. It also exhibited significantly $(\mathrm{P}<0.05)$ anti-inflammatory by $0.11 \pm 0.02,0.11 \pm 0.03,0.08 \pm 0.01$ respectively. The preliminary phytochemical screening of the plant extract revealed the presence of flavonoids, steroids, tannins and saponins while the effect of flavonoids, steroids and tannins on analgesic and inflammatory has been reported. The intraperitoneal median lethal dose $\left(\mathrm{LD}_{50}\right)$ value of the extract was found to be $3807.8 \mathrm{mgkg}^{-1}$ body weights. The result obtained from this study shows that the extract of Ficus iteophylla contained phytochemical constituents with analgesic and anti-inflammatory activities, therefore the leaf part of the plant could be used in the management of pain and inflammatory conditions.
\end{abstract}

Key words: Ficus iteophylla, analgesic, anti-inflammatory, intraperitoneal

\section{Introduction}

Throughout the ages, humans have relied on Nature for their basic needs for the production of food-stuffs, shelters, clothing, means of transportation, fertilizers, flavours and fragrances, and, not the least, medicines. Medicinal plants typically contain mixtures of different chemical compounds that may act individually, additively or in synergy to improve health. Man has used several therapies for the management of pain (Ahmadiani et al., 1998) and medicinal herbs are mostly used due to their availability, affordability and less side effects; example Papaver somniferum from which morphine, a ptototype of opiate analgesic drug was isolated (Bertram, 2001).

Pain is an unpleasant sensation which in many cases represents the only symptom for diagnosis of several diseases (Bertram, 2001). Non-steroidal anti-inflammatory drugs (NSAIDS) and opioids are used in management of mild to moderate and severe pains respectively. These drugs have serious limitations due to their side effects such as gastrointestinal irritation, tolerance and dependency (Howland and Mycek, 2006). There is therefore, a need to intensify research with the aim of developing efficacious agents with low toxicity profile (Howland and Mycek, 2006).

A number of medicinal plants are used in developing countries for the management of pain and inflammatory conditions. The validation of the folkloric claims of these medicinal plants will provide scientific basis for the development of their bioactive constituents. These could provide novel lead compounds or precursors in drug development; one of such medicinal plants with ethnomedical claims in pain and inflammatory conditions is Ficus iteophylla.

Ficus iteophylla (Shirinya in Hausa) is of the family moraceae. It is commonly found in the Sudan savanna forest and into the Sahel where it is appreciably smaller, extending across the northern part of the region from Senegal to northern Nigeria (Dalziel, 1955). The bark contains a soft sticky gum which does not remain fluid but does not harden (Dalziel, 1955). In ethnomedicine, root is used in Senegal for treating paralysis, tuberculosis, insanity, epilepsies, convulsion, spasm and pulmonary troubles (Burkill, 1997). The bark is used to treat dysentery, rheumatic pain and as pain killer (Burkill, 1997). The leaf part was reported to have antibacterial activity (Ahmadu et al, 2006). Previous phytochemical studies on the leaf led to isolation of two furanocoumarines, psoralen and bergapten (Ahmadu et al, 2004), two flavonoid glycosides which are Kaempferol-3-o- rutinosides and Quercitin-3-o-rutinosides (Ahmadu et al, 2006).The present study to the best of our search is the first report to evaluate the leaf part of the plant for analgesic and inflammatory activities.

\section{Materials and Methods Plant material}

The plant samples were collected from Ahmadu Bello University, Zaria Nigeria in the month of March, 2006. It was 
authenticated by comparing with the existing one by Mallam Musa Muhammad of the Herbarium section of the Department of Biological Sciences, Ahmadu Bello University, Zaria, Nigeria.

\section{Preparation of the extract}

The leaves parts were air dried at room temperature under shade for between 9 - 14 days and then crushed into coarse powder with a pestle and mortal. About $850 \mathrm{~g}$ of the powdered leaves was exhaustively extracted with petroleum ether using soxhlet apparatus, the marc was dried and extracted with ethanol in same way. The solvent in both cases were removed at reduced pressure to give $15 \mathrm{~g}$ and $50 \mathrm{~g}$ of petroleum ether and ethanol respectively.

\section{Phytochemical Screening}

The ethanol leaves extract was subjected to phytochemical screening for the presence of alkaloids, flavonoids, tannins, saponins and steroids using standard procedure (Silva et al., 1998).

\section{Animals}

Swiss albino mice (19-23g) and rats (18-23g) of either sex were used for the study. The animals were kept and maintained under laboratory conditions of temperature, humidity and light, and were allowed free access to food and water ad labium. All experiments were conducted in accordance with animal use ethics as accepted internationally (C.I.O.M.S, 1985)

\section{Drug}

Ketoprofen injection manufactured by Lek pharmaceutical company Yugoslavia and Morphine injection manufactured by martindale USA were used as standard drugs.

\section{Acute toxicity study}

Acute toxicity study (i.p) to estimate the safety of the leaves extract was performed on mice using the method of Lorke (1983). The study was divided into two phases. In the first phase, nine mice of either sex were divided into three groups of three mice each. Group I received $10 \mathrm{mg} / \mathrm{kg}$ of leaves extract while group II and III received 100 and $1000 \mathrm{mg} / \mathrm{kg}$ leaves extract respectively. The mice were observed for signs and symptoms of toxicity and mortality for twenty four hours after treatment (no mortality). In the second phase three mice were divided into three groups of one mouse each, the first received leaves extract at a dose of $1600 \mathrm{mg} / \mathrm{kg}$ while the second and third groups received leaves extract at doses 2900 and $5000 \mathrm{mg} / \mathrm{kg}$ respectively. The mice were also observed for 24hours (mortality occur at $5000 \mathrm{mg} / \mathrm{kg}$ ). The final $\mathrm{LD}_{50} \mathrm{Was}$ calculated as the square root of the product of the lowest lethal dose and the highest non-lethal dose i.e the geometric mean of consecutive doses for which 0 and $100 \%$ survival rates were recorded.

\section{Analgesic studies \\ Acetic acid-induced writhing test in mice}

The test was conducted employing Koster et al (1959) method. Swiss albino mice were divided into 5 groups of 6 mice each. The first group served as control and was given $10 \mathrm{ml} / \mathrm{kg}$ i.p normal saline to act as negative control. Groups II, III, and IV received 100, 200, and 400mg extract per kg body weight i.p respectively, while the V group was given $10 \mathrm{mg}$ ketoprofen per kg body weight i.p to act as positive control. Thirty minutes later, each mouse was injected with $(0.06 \%$ acetic acid of $1 \mathrm{ml}$ per $100 \mathrm{~g}$ i.p). The number of abdominal constriction for each mouse was counted five minutes after injection of acetic acid for a period of ten minutes. Percentage inhibition of writhing was calculated using the formula.

Inhibition \% $=$ Mean no of writhes $($ control $)-$ mean no of writhes (test) $\times 100$

Mean no of writhes (control)

\section{Hot plate test method}

The method of Lanhers et al, (1992) and Williamson et al, (1996) was adopted. Mice were placed on a hot plate maintained at temperature of $50 \pm 1^{0} \mathrm{C}$. The time taken for either paw licking or jumping (pain reaction time) by each mouse was recorded. Mice that showed initial nociceptive response within 20 seconds were selected and used for the study. The mice were then divided into 5 groups of 6 mice per group. Group I served as negative control and received $10 \mathrm{ml}$ per $\mathrm{kg}$ of $2 \%$ acacia (vehicle) while group II, II and IV received extract (i.p) at dose 100, 200 and 400mg per kg respectively and the last group received Morphine $5 \mathrm{mg}$ per $\mathrm{kg}$ (i.p) to act as positive control. Thirty minutes later each mouse was placed on a hot plate and the pain reaction time recorded.

\section{Anti-inflammatory study \\ Carrageenan-induced paw oedema in rats}

The method described by Winter et, al (1962) was used. Thirty rats were divided into 5 groups each consisting of 6 rats each. Group I received $1 \mathrm{ml}$ per kg normal saline (negative control), group II, III and IV received extract at doses of 100 , 
200, and 400mg per kg respectively while the last group received ketoprofen 10mg per kg (positive control). Thirty minutes later, $0.1 \mathrm{ml}$ of sterile saline solution of $1 \%$ carrageenan was injected into the sub-plantar surface of the left hind paw. Paw diameter was measured using Vernier Calipher at time 0, 1, 2, 3 and 4 hours after carrageenan administration within 5-8 minutes.

\section{Statistical analysis}

The results of the experiments were expressed as Mean \pm S.E.M. The mean values of control groups were compared with the mean value of treated groups using one way ANOVA. Results were considered significant at. $\mathrm{P}<0.05$.

\section{Results}

The phytochemical screening of the ethanol extract of Ficus iteophylla revealed the presence of flavonoids, steroids, tannins and saponins.

Table 1 Phytochemical analysis of the ethanol extract of Ficus iteophylla

\begin{tabular}{ll}
\hline \multicolumn{1}{c}{ Test } & Result \\
\hline ALKALOIDS & \\
(a) Drangendoff's & - \\
(b) Mayers & - \\
(c) Wagner's & + \\
FLAVONOIDS & + \\
(a) Shinoda & \\
(b) Sodium hydroxide & + \\
SAPONINS & \\
Frothing & + \\
TANNINS & + \\
(a) Ferric Chloride & \\
(b) Lead acetate & + \\
STEROIDAL NUCLEUS & + \\
(a) Salkwoski & + \\
(b) Liberman-Butchard & \\
\hline
\end{tabular}

$+=$ positive, indicating presence

- = negative, indicating absence

The intraperitoneal $\left(\mathrm{LD}_{50}\right)$ of the ethanol extract of Ficus iteophylla in mice was found to be $3807.8 \mathrm{mgkg}^{-1}$. The extract at doses of 100,200 and $400 \mathrm{mg} / \mathrm{kg}$ significantly $(\mathrm{P}<0.05)$ reduced the number of acetic acid induced abdominal constriction by $1.5 \pm 0.43,3.0 \pm 0.82$ and $1.0 \pm 0.82$ respectively. Ketopfofen $(10 \mathrm{mg} / \mathrm{kg})$ produced $4.30 \pm 1.28$ reductions in abdominal constriction (Table 2). In the hot plate test, the extract at 100,200 , and $400 \mathrm{mg} / \mathrm{kg}$ significantly $(\mathrm{P}<0.05)$ increased the after treatment reaction time from $1.33 \pm 0.15$ in normal saline treated group to $1.80 \pm 0.26$ in group treated with extract $200 \mathrm{mg} / \mathrm{kg}$ (Table 3).

In the normal saline treated animals, subplantar injection of $1 \%$ carrageenan suspension produced a local oedema reaching its maximum at $3 \mathrm{~h}$. The extract of Ficus iteophylla significantly $(\mathrm{P}<0.05)$ inhibited the progressive increase and decrease in paw oedema, in a not dose dependent manner (Table 4). The anti-inflammatory effect of the extract was intense, comparing favourably at $400 \mathrm{mg} / \mathrm{kg}$ with that of ketoprofen $10 \mathrm{mg} / \mathrm{kg}$. The average inhibition of each concentration from $1 \mathrm{hr}$. to $4 \mathrm{hr}$. is expressed as \% inhibition.

Table 2:Efect of ehanolic extract of F.iteophylla leaves and ketoprofen on Acetic acis induced writhings in Mice.

\begin{tabular}{llc}
\hline Treatment (mg/kg) & mean number of writhes \pm SEM & $\%$ \\
\hline Normal Saline & $26.6 \pm 3.16$ & 94.36 \\
F.I $(100)$ & $1.5 \pm 0.43^{\mathrm{a}}$ & 88.72 \\
F.I (200) & $3.0 \pm 0.82^{\mathrm{a}}$ & 96.24 \\
F.I(400) & $1.0 \pm 0.82^{\mathrm{a}}$ & 83.83 \\
Ketoprofem(10) & $4.3 \pm 1.28^{\mathrm{b}}$ & \\
\hline
\end{tabular}

Data presented as mean $\pm \mathrm{SEM}, \mathrm{n}=6$ for all groups ${ }^{\mathrm{a}}$ and ${ }^{\mathrm{b}}$ are significantly different from control at $\mathrm{p}<0.05$ 
Table 3: Effect of ethnol extract of F.Iteophylla leaves on pain reaction time in hot plate test in mice

\begin{tabular}{|l|l|}
\hline Treatment/Dose & Pain reaction \pm SEM \\
\hline Normal Saline $(10 \mathrm{ml} / \mathrm{kg})$ & $1.33 \pm 0.15$ \\
\hline F.I $(100 \mathrm{mg} / \mathrm{kg})$ & $1.43 \pm 0.10^{\mathrm{a}}$ \\
\hline F.I $(200 \mathrm{mg} / \mathrm{kg})$ & $1.80 \pm 0.26^{\mathrm{a}}$ \\
\hline F.I $(400 \mathrm{mg} / \mathrm{kg})$ & $1.53 \pm 0.06^{\mathrm{a}}$ \\
\hline Morphine $(5 \mathrm{mg} / \mathrm{kg})$ & $16.60 \pm 2.50^{\mathrm{b}}$ \\
\hline & \\
\hline & \\
\hline
\end{tabular}

Table 4: Effect of the ethanol extract of F.I leaves on carrageenan induced paw oedema in rats and percentage inhibition.

\begin{tabular}{|llllll|}
\hline \multicolumn{7}{c|}{ Mean per oedema diameter \pm SEM } \\
\cline { 2 - 5 } & $1 \mathrm{hr}$ & $2 \mathrm{hr}$ & $3 \mathrm{hr}$ & $4 \mathrm{hr}$ & \% inhibition \\
\hline Treatment/Dose & $0.16 \pm 0.01$ & $0.23 \pm 0.01$ & $0.29 \pm 0.02$ & $0.21 \pm 0.02$ & \\
\hline Normal Saline $(1 \mathrm{ml} / \mathrm{kg})$ & $(-)$ & $(-)$ & $(-)$ & $(-)$ & $(-)$ \\
& $0.10 \pm 0.02^{\mathrm{a}}$ & $0.11 \pm 0.02^{\mathrm{a}}$ & $0.10 \pm 0.03^{\mathrm{a}}$ & $0.11 \pm 0.02^{\mathrm{a}}$ & \\
& $(37.50)$ & $(52.17)$ & $(65.52)$ & $(47.62)$ & 50.70 \\
\hline F.I $(100 \mathrm{mg} / \mathrm{kg})$ & $0.11 \pm 0.02^{\mathrm{a}}$ & $0.11 \pm 0.02^{\mathrm{a}}$ & $0.11 \pm 0.03^{\mathrm{a}}$ & $0.11 \pm 0.04^{\mathrm{a}}$ & \\
& $(31.25)$ & $(52.17)$ & $(62.07)$ & $(47.62)$ & 48.28 \\
\hline F.I $(200 \mathrm{mg} / \mathrm{kg})$ & $0.07 \pm 0.01^{\mathrm{a}}$ & $0.09 \pm 0.02^{\mathrm{a}}$ & $0.08 \pm 0.01^{\mathrm{a}}$ & $0.08 \pm 0.01^{\mathrm{a}}$ & \\
& $(56.25)$ & $(60.87)$ & $(72.41)$ & $(61.90)$ & 62.86 \\
\hline F.I(400mg/kg) & $0.07 \pm 0.01^{\mathrm{b}}$ & $0.09 \pm 0.01^{\mathrm{b}}$ & $0.08 \pm 0.02^{\mathrm{b}}$ & $0.05 \pm 0.01^{\mathrm{b}}$ & \\
\hline Ketoprofem $(10 \mathrm{mg} / \mathrm{kg})$ & $(56.25)$ & $(60.87)$ & $(72.41)$ & $(76.19)$ & 66.43 \\
\hline
\end{tabular}

$\mathrm{n}=6$ for all groups a and $\mathrm{b}$ are significant compared with with control at $\mathrm{p}<0.05$

Figures in paranthesis represent percentage inhibition of inflammation

\section{Discussion}

The phytochemical screening revealed the presence of flavonoids, steroids, tannins, saponins. The relatively high $\mathrm{LD}_{50}$, value $3807.8 \mathrm{mg} / \mathrm{kg}$ obtained in this study for Ficus iteophylla ethanolic leaves extract suggests that the plant extract is relatively safe to mice (Loomes and Hayes, 1996; Matsumura, 1975).

The ethanol leaf extract showed analgesic activity in acetic acid induced writhing test in mice, thus indicating that the leaves extract possessed pheripheral mediated analgesic activity. The peripheral anangesic effect of the plant extract may be mediated via inhibition of cyclo-oxygenases. This hyphothesis is in consonance with those of Williamson et al, (1996) and Koster et al, (1959) who have postulated that acetic acid-induced writhing method is a useful technique for the evaluation of peripherially-acting analgesic drugs.

Pain induced by thermal stimulus of the hot plate is specific for centrally mediated nociception (Florence et al, 1997). The ability of the leaves extract to prolong the reaction latency to pain thermally induced in mice suggests that the leaves extract has some central analgesic activity, this is in accordance with Williamson et al, (1996) and Koster et al, (1959). In the anti-inflammatory studies, the percentage inhibition obtained showed that the leaves extract exhibited significantly reduction in the oedema in the hind paw of the rats. This probably may be due to cyclooxygenase (cox) pathway of arachidonate metabolism produces prostaglandins, which have a variety of effects on blood vessels, on nerve endings and on cells involved in inflammation (Bertram, 2001). The extracts probably produces its anti-inflammatory effect by inhibiting the release synthesis of inflammatory mediators including polypeptide kinins and prostaglandins. 
The analgesic and anti-inflammatory effects of flavonoids, steroids and tannins have been reported (Das et al, 1989). based on this finding it seems that the analgesic and anti-inflammatory effects produced by the extract of Ficus iteophylla leaves may be attributed individually or collectively to the flavonoids, steroids and tannins present in accordance with (Das et al, 1989).

\section{Conclusion}

The study has shown that the ethanol extract of Ficus iteophylla leaves does possess significant anti nociceptive and anti-inflammatory effects in laboratory animals at the doses investigated therefore the leaves part of the plant could be used in the management of pain and inflammatory conditions. It also contains some biologically active constituents worthy of further investigations.

\section{References}

1.Ahmadiani A., Fereidoni M., Semnanian S., Kamalinejad M and Seremi S (1998). Antinoceptive and anti-inflammatory effects of Sambucus ebulus rhizome extract in rats. J. Ethnopharmacol.61: 229-235.

2. Ahmadu, A. A., Haruna, A. K., Garba, M., Usman, H. and Ebeshi, B. U (2004). Flavonoid Glycosides From The Leaves Of Daniellia oliveri Nig. J. Nat.Prod. And Med. .8: 67-68.

3. Ahmadu A.A, Akpuh I.N, Abubakar M.U, Hassan H.S and Sule M.I (2006). Phytochemical and antibacteria activity of Ficus iteophylla linn leaves (moraceae). Nigeria journal of Pharmaceutical Research,. 5:97-101.

4. Bertram, G. K. (2001). Basic and Clinical Pharmacology. 8ed. McGraw-Hill Companies.

5. New York. Pp 596-597.

6. Burkill, H. M (1997). The Useful Plants of West Tropical Africa.Vol 4. BPC Whitefriars Ltd. Royal Botanic Gardens Kew Pp 181

7. Council for International Organisation of Medical Sciences (1985). 1211 Geneva,Switzerland.

8. Dalziel, J. M. (1955). Floral of West Tropical Africa. A Crown Agents for oversea Publication. Pp 280-281.

9. Das, P. C., Das, A. and Mandal, S. (1989). Antimicrobial and anti-inflammatory activities of the seed Kernel of Mangifera indica. Fitoterapia, 60:235-240.

10. Florence N, Claire S, Olga V, Rafaël M, Pascale C, Serge T, Marie C, Fournié Z and Bernard P (1997). Painsuppressive effects on various nociceptive stimuli (thermal, Chemical, electrical and inflammatory) of the first orally active enkephalin-Metabolizing enzyme inhibitor RB 120. Pain . 73 (3): 383-391.

11. Koster. R; Anderson. M and Debeer, E. J (1959). Acetic acid for analgesic screening.Federation Proceeding. 18. Pp412-417.

12. Howland RD, Mycek MJ (2006). Lippincott’s Illustration Review: Pharmacology. Harvey, RA, Champe PC (eds.) Lippincott Williams \& Wilkins publishers London. pp. 157-168.

13. Lanhers MC, Fleurentin J, Mortier F, Vinche A, Younos C. 1992. Anti-inflammatory and analgesic effects of an aqueous extract of Harpagophytum procumbens. Planta Med 58: 117- 123.

14. Loomes, T. A. and Hayes. A. W (1996). Loomes's essential of toxicology. $4^{\text {th }}$ ed. California, Academic press: 208245.

15. Lorke, D. A. (1983). A New Approach to practical acute toxicity testing. Archives of Toxicology. 54: 275-287

16. Matsumara, F. (1975) Toxicology of Insecticides. Plenum press, New York and London Pp 24-26

17. Silva, G. L, Chai, H., Farnsworth, N. R., and Gupta, M. P. (1998). In Natural Products Isolation. Edited by Richard Carnell. A Humana Press Publication. New Jersey. Pp 349, 356-359.

18. Williamson EM, Okpako DT, Evans FJ. (1996). Pharmacological Methods in Phytotherapy Research. Volume 1. Selection, Preparation and Pharmacological Evaluation of Plant Materials.John Wiley: Chichester, 184-186.

19. Winter, C. A., Risely, E. A. and Nuss, G. W. (1962). Carrageenan-induced oedema in the hind paw of the rats as an assay for anti-inflammatory drugs. Proc. Soc. Exp. Bio.Med. 111:544-547. 